\title{
Herbal Piscicides in Inland Aquaculture-A Review
}

\section{Das SK${ }^{1 *}$, Mondal B ${ }^{2}$, Biswas $\mathrm{B}^{3}$ and Mandal $\mathrm{A}^{4}$}

${ }^{1}$ Department of Aquaculture, Faculty of Fishery Sciences, West Bengal University of Animal and Fishery Sciences, Kolkata, India

${ }^{2}$ Department of Aquaculture, Faculty of Fishery Sciences, West Bengal University of Animal and Fishery Sciences, Kolkata, India

${ }^{3}$ Department of Aquaculture, Faculty of Fishery Sciences, West Bengal University of Animal and Fishery Sciences, Kolkata, India

${ }^{4}$ Department of Aquaculture, College of Fisheries, Guru Angad Dev Veterinary and Animal Sciences University, Punjab, India

*Corresponding author: Das SK, Department of Aquaculture, Faculty of Fishery Sciences, West Bengal University of Animal and Fishery Sciences, 5, Budherhat Road, Panchasayar, Chakgaria, Kolkata 700094, India, Tel: +919433130947;

Email: skdaswbuafs@gmail.com

\section{Abstract}

Eradication of predatory and weed fishes is one of the most important steps in pre-stocking management of pond based aquaculture. The chemical piscicides are mostly pesticides of diverse nature, designed for land based agricultural practices. In the aquatic environment in fish culture ponds, besides acting as piscicides, they are bound to impact the environment negatively because of their long persistency and non-target oriented in action. Consequent to this, a number of plants derived, low cost and locally available materials became popular as piscicides particularly in the moderately intensive inland aquaculture all over the globe. The present paper reviewed a brief account of the herbal piscicides with particular reference to Indian aquaculture.

Keywords: Herbal piscicides; Weed fish; Traditional knowledge

\section{Background}

Scientific management of inland aquaculture systems like, ponds, tanks etc. are often limited with problems like invasion of unwanted organisms including fishes, insects etc. Aquaculture ponds very often house undesirable species of fish, their eggs, fry which may be introduced when unfiltered surface water is used to fill the production ponds. Most of the time, such introductions are the result of accidental or intentional stocking by humans. Unwanted fish may enter fish culture ponds through water supplies, birds or along with fish seed 


\section{Journal of Ecology \& Natural Resources}

brought into fish farm and can account for up to $40 \%$ losses in the commercial fish and shrimp harvest [1]. Thus, successful pond management requires more than just stocking fish as weed fish along with the predacious fishes besides preying, compete with the desired species for food, space and dissolved oxygen are required to be removed well in advance of stocking fry and fingerlings $[2,3]$.

Methods like dewatering and de-silting of ponds, repeated netting operations, hooks and lines with baits in eradication of predatory and weed fishes are proved to be incomplete and uneconomical [4]. As a result, limited poisoning of the pond with selective toxicant became popular for the purpose [5]. Fish toxicants have long been considered as the best rehabilitation tool available for fishery management [6-8]. Synthetic piscicides are not degradable, pose the problems of environmental resistance, pest resurgence and have detrimental effects on non-target organisms [9]. On the other hand, plant poisons extracted from flowers, bark, pulp, seeds, roots, leaves and even the entire plant [10] are environment friendly. Therefore, use of herbal piscicides are always advantageous over chemical ones due to their effectiveness in killing targeted organisms, short-term action, faster degradation, and non-residual effect [11].

\section{History of Plant Derived Piscicides in Fishing}

Plant derivatives have been used since prehistoric times for incapacitation and killing of fish. Use of the fish poisons is very old practice in the history of human kind. In 1212 AD, King Frederick II prohibited the use of certain plant piscicides and by the 15th century similar laws had been decreed in other European countries as well [12]. Primitive peoples in South America and Southeast Asia applied rotenone containing plants in fresh and salt waters to collect fish for food [13]. Fishing using plant poisons is an age old tradition all over the world and is still practiced through-out many places in the world [14]. The Chinese employed "fishing plants", particularly "tea seed cake" made from saponin bearing seeds of Camellia sp. to control competing and predaceous fish in fish culture ponds [15]. Extracts from walnut hulls have a long biomedical history, including use to immobilize and capture fish [16]. Today, rotenone, saponin, and walnut extracts are still of interest to eradicate unwanted fish.

\section{Herbal Piscicides}

Generally to avoid the hazardous effect of chemicals, some less toxic native plant derivatives are now used in India as fish poisons [17]. Fish poisons of plant origin are used for cultural, commercial and environmental reason in waterways management for the control of non-game fish species [18]. Many plants contain chemicals which have traditionally been used to harvest fish and also to monitor various pests in almost all parts of the world [19]. The herbal piscicides are varied as plants are virtually inexhaustible source of structurally diverse biologically active substances [20]. Administration of plant extracts has been in use for treating animal and human diseases since ancient times. These plants used in treating human ailments and animal diseases are often considered as poisonous and their beneficial effects often occur at lower doses whereas, overdose can induce poisoning [21]. Several plants belonging to different families, having a number of compounds (saponins; tannins; alkaloids; alkenyl phenols; di and tri terpenoids; etc.) with high pesticidal activity are used to control predatory fish; disease causing insects such as mosquito larvae and harmful fresh water snails [22,23]. Moreover, they are often used to control competing species, eradicate predators, control parasites, and conserve or restore native species because of their less toxicity to aquatic organisms and non degradation to the environment [24]. The plant products degrade easily within 7-12 days and are considered environmentally benign as they act as manures following biodegradation $[25,26]$. Herbal piscicides upon decomposition favours $\mathrm{N}: \mathrm{P}$ ratio to be in the desirable range of $4: 1$ - 8:1 [11].

The active ingredients of plant toxins are released in the water environment by mashing the appropriate plant parts directly without any processing. Poisoning is generally done in stagnant pools or slow-flowing streams and rivers which allow the pounded part of plant to concentrate without being washed away or diluted by current. Sometimes streams are partly blocked to slow down the flow of water. Most icthiotoxic plant poisons initially works as stupefying or paralysing agent and later lead to death of the fish. Piscicidal plants used in fishing actually stupefy the fishes without killing the whole fish stock like chemical piscicides [27]. Biochemical compounds inherent in piscicidal plants stun the fishes when it passes through its gills or ingested directly. The fishes come to the surface because of lack of dissolved oxygen and exhibit abnormal behaviours due to asphyxia, haemorrhages in internal organs, nervous breakdown. Some common plant derivatives used as piscicides at commercial level is listed below:

\section{Mahua Oil Cake}

Mahua oil cake (MOC), a derivative from the plant Bassia latifolia, an Indian tropical tree found largely in the central and north Indian plains and forests, possesses 
evergreen or semi-evergreen foliage, and belongs to the family Sapotaceae, is extensively used in aquaculture practices in India, both as a fish toxicant and as organic manure in fish ponds after its toxic effects are completely diminished. Saponin is the active compound responsible for toxic effect of mahua oil cake. Plant-derived saponins have been widely used in non-intensive aquaculture operations throughout Asia and Africa and became attractive because of their low toxicity to mammals [28]. The cake is the remaining after oil has been extracted from mahua seeds [29]. The cake is powdered and either applied over the water surface or alternatively, cake can be soaked overnight and spread over the pond surface at a recommended dosage of $250-300 \mathrm{mg} \mathrm{L}^{-1}$.

\section{Derris Root Powder}

The most common herbal poison used in fish pond is rotenone inherent in derris (Derris elliptica) root powder that contains $5 \%$ rotenone. Rotenone is the main piscicide used internationally for eradicating and controlling pest fishes in freshwaters [30,31]. The first documented use of rotenone in fishery management was by the Michigan Institute of Fisheries Research in 1934 [32]. Rotenone is a white odorless substance in Derris root which inhibit respiration in fish.

\section{Croton Seed}

Croton tiglium L. is a shrub native to South East Asia and belongs to the family Euphorbiaceae. It is indigenous to India and widely distributed in North-Eastern part of India. In the state of Manipur, India, it is used as folk medicine for treating gastrointestinal disorders in human. As the seeds and young leaves of this plant are extremely toxic to fishes, it has been extensively used as a piscicides for killing fishes for human consumption. The pisicidal and molluscidal effects of this plant had been reported by several authors [33].

\section{Tobacco Waste}

Tobacco plant (Nicotiana tobaccum) leaf is one of such plant derivative with pesticidal properties. The active ingredient in tobacco leaf is nicotine which constitutes 2$5 \%$ as dry weight of the leaf [34]. Tobacco wastes are added to milkfish ponds as manure in Southeast Asia with the advantage that nicotine kills aquatic insects [35]. In India, Konar suggested that nicotine may be very useful both as a fish-collecting aid and toxicant [36]. The combination of nicotine from the tobacco and oxygendepletion resulting from the decomposition of the plant acts as poison that suffocates unwanted fish, fish parasites, and possibly bacteria.

\section{Tea Seed Cake}

Tea seed cake is the residue of Camellia sp. seeds after oil extraction that contains $5.2-7.2 \%$ of saponin which is a haemolytic toxin in blood [37]. Because of it's effectiveness, many farmers used to apply it for eradicating predator fishes, shellfish or tadpoles in the fish and shrimp ponds [38]. For use as toxicant tea seed cake is ground, soaked overnight and then can be applied at $525-675 \mathrm{~kg} \mathrm{Ha}^{-1}$ [39]. As high amount of tea seed cake can rise the acidity level of water simultaneous application of quick lime is recommended.

\section{Piscicidal Plants of India}

A good number of plants either as a whole or in parts (Table 1) are in use in various parts of the country either as fish aggregator upon stupefying agent of the active ingredients or as a piscicide in controlling unwanted and predatory fish in the culture pond. The variability in use depends upon the availability of the plants, traditional knowledge about the plants through the ages and, type and intensity of operation by the farmers.

\begin{tabular}{|c|c|c|c|c|c|}
\hline Scientific Name & Family & Habit & Local Name & Parts Used & Reference \\
\hline Abrus precatorius & Fabaceae & Plant & - & Seed & Krishan [40] \\
\hline Acacia catechu & Fabaceae & Tree & Khair & Stem & Nasiruddin et al., Krishan $[40,41]$ \\
\hline Acacia chundra & Mimosaceae & Tree & Laal Khair & $\begin{array}{l}\text { Bark and } \\
\text { Leaf }\end{array}$ & Raha and Mallick, Krishan, $[40,42]$ \\
\hline Acacia pennata & Fabaceae & Climber & Agali & Bark & $\begin{array}{c}\text { Negi and Kanwal, Rajput and Gaur, } \\
\text { Krishan }[40,43,44]\end{array}$ \\
\hline Acacia nilotica & Fabaceae & Tree & Babool & Whole plant & Krishan, Kerezsy $[40,45]$ \\
\hline Ageratum conyzoides & Asteraceae. & Herb & - & Whole plant & Krishan, Zhao et al., Dimri, $[40,46,47]$ \\
\hline Argemone Mexicana & Papavaraceae. & Herb & - & seed & Sinha and Munshi, Krishan $[40,48]$ \\
\hline Achyranthus aspera & Amaranthaceae & Herb & - & Whole plant & Fafioye, Dixit $[9,49]$ \\
\hline Ageratum conyzoidus & Asteraceae & Herb & Goat weed, & Whole plant & Krishan [40] \\
\hline
\end{tabular}




\section{Journal of Ecology \& Natural Resources}

\begin{tabular}{|c|c|c|c|c|c|}
\hline & & & pudina & & \\
\hline Anagallis arvensis & Primulaceae & Herb & - & Whole plant & Krishan [40] \\
\hline Butea monosperma & Papilionaceae & & Porasu & Seed & Alagesaboopathi [50] \\
\hline Calotropis gigantea & Asclepiadaceae & Herb & Akanda & Root & $\begin{array}{c}\text { Raha and Mallick, Alagesaboopathi } \\
{[42,50]}\end{array}$ \\
\hline Casearia elliptica & Flacourtiaceae & Tree & Chorcho & Fruit & $\begin{array}{l}\text { Raha and Mallick, Rajput and Gaur } \\
{[42,44]}\end{array}$ \\
\hline Cassia fistula & Caesalpiniaceae & Tree & Sodal & Stem, bark & Raha and Mallick [42] \\
\hline Cleistanthus collinus & Euphorbiaceae & Tree & Oduvan & Leaf & Alagesaboopathi [50] \\
\hline Cordia dichotoma & Boraginaceae & Tree & Buch & Leaf and fruit & Raha and Mallick [42] \\
\hline Costus speciosus & Zingiberaceae & Herb & Kamuk & Rhizome & Raha and Mallick [42] \\
\hline Drimia indica & Liliaceae & Herb & Bon Piyaz & Bulb & Raha and Mallick [42] \\
\hline Gardenia latifolia & Rubiaceae & Tree & Popro & Stem bark & Raha and Mallick [42] \\
\hline Gloriosa superba & Liliaceae & Climber & Ulatchandal & Tuber & Raha and Mallick [42] \\
\hline Haldina cordifolia & Rubiaceae & Tree & Kelkadam & Stem Bark & Raha and Mallick [42] \\
\hline Helicteres isora & Sterculiaceae & Shrub & Ant-Mochra & Bark & Raha and Mallick [42] \\
\hline $\begin{array}{c}\text { Holarrhena } \\
\text { pubescens }\end{array}$ & Apocynaceae & Tree & Indrajab & Stem Bark & Raha and Mallick [42] \\
\hline $\begin{array}{l}\text { Holoptelea } \\
\text { integrifolia }\end{array}$ & Ulmaceae & Tree & Chhalla & Leaf & Raha and Mallick [42] \\
\hline $\begin{array}{c}\text { Hybanthus } \\
\text { enneaspermus }\end{array}$ & Violaceae & Herb & Khetpapra & Whole plant & Raha and Mallick [42] \\
\hline Madhuca indica & Sapotaceae & Tree & Mahua & Seed & $\begin{array}{l}\text { Raha and Mallick, Rajput and Gaur } \\
\qquad[42,44]\end{array}$ \\
\hline Milletia ferruginea & Leguminosae, & Tree & Birbira & Seed & Banouzi et al. [51] \\
\hline Plumbago zeylanica & Plumbaginacea€ & Herb & Tutta & Root & Raha and Mallick [42] \\
\hline Polygonum barbatum & Polygonaceae & Herb & Panimarich & Leaf & Raha and Mallick [42] \\
\hline \begin{tabular}{|l|}
$\begin{array}{l}\text { Polygonum } \\
\text { hydropiper }\end{array}$ \\
\end{tabular} & Polygonaceae & Herb & & Whole plant & Kalita et al. [52] \\
\hline Pongamia pinnata & Fabaceae & Tree & Karanja & Seed & $\begin{array}{l}\text { Raha and Mallick, Nasiruddin et al. } \\
{[41,42]}\end{array}$ \\
\hline Schleichra oleosa & Sapindaceae & Tree & Kusum & $\begin{array}{c}\text { Seed, Stem and } \\
\text { Bark }\end{array}$ & Raha and Mallick [42] \\
\hline Strychnos nux-vomicd & Loganiaceae & Tree & Kuchla & Seed & Raha and Mallick [42] \\
\hline Thevetia peruviana & Apocynaceae & Plant & & Leaf, bark & Oti and Ukpabi [53] Singh et al., [53,54] \\
\hline Vetilago denticulate & Rhamnaceae & $\begin{array}{l}\text { Woody } \\
\text { Climber }\end{array}$ & Bonga-Sayam & Stem Bark & Raha and Mallick [42] \\
\hline
\end{tabular}

Table 1: Some piscicidal and fish stupefying plants documented to be found in India.

Ethnic Tribes in India and Use of Plants as Indigenous Technical Knowledge in Fishing

All over the globe, indigenous people use various fish poisons to kill the fishes [55]. Most of the tribal inhabitants from different states of India mainly survive on their traditional knowledge base. Tribal people using various plants for medicinal and other purposes extend the use notion for herbal fish stupefying plants [52,56,57]. With the spread of civilization, such method of fishing relies on wholesome destruction of fishes and other aquatic organisms of all sizes, is forbidden in most countries. But in remote areas it is being practised as usual and even suitable plants are being cultivated too. People who live near the water bodies mostly in the remote and hilly areas use various conventional methods of catching fishes. This kind of fishing is mostly done during the dry season, in small and seasonal ponds to facilitate effective control of environmental conditions and spread of poison quickly. In, most cases fishing with poison is considered as women fishing method as in 


\section{Journal of Ecology \& Natural Resources}

general they collect the plant material and provide the poison [58].

Many plants having piscicidal property have been reported from different states of India. Chopra et al. reported 112 species of plants having piscicidal action [59]. More than 40 plants are found in North-east India, around 15 species of plants are used by Bhil tribe of Madhya Pradesh, the state of Arunachal Pradesh harbours more than 500 species of plants of medicinal and pharmacological significance, out of which $30 \%$ plants are used as fish poison, there have been 21 plant species as fish poison in the Travancore and 28 plants belonging to 16 families were used for fish poisoning in Kasargod district of Kerala [57,60-64].

Sasi and Mohan investigated that a total of 41 species of piscicidal plants belonging to 18 families and 33 genera are found in Kerala [65]. The usage of fish poisonous plants by the Malayadiyars tribes of Pamba river basin reported by Bourdillon in 1892 was considered as the first report [66]. The tribal community Malai Pandaram in Achankovil river basin of Kerala generally uses fish stupefying methods in summer season. Slow moving river, streams or ponds were selected for fish poisoning. The branches of plants like Madhuca neriifolia (Moon) and Acacia caesia were placed in water at selected areas, the former for the shade and later to protect fishes from the water bird. Rice, tapioca etc. were put into water as food to attract fishes from various part of the river from the area of poisoning. After one or two days the flow of the river and streams are barred by diverting the water current. Crushed parts of plants Acacia caesia, Albizia lebbeck, Archidendron bigeminum etc are put into the water for catching fish.

Heda and Kulkarni documented fish stupefying plants and their methods of application used by the Gond tribal people of Mendha village of the Gadchiroli district in Maharashtra [67]. Leaves, bark, fruits, shoots of plants like Olax sp., Careya arborea, Cleistanthus collinus, Costus speciosus, Madhuca indica and Chloroxylon swietenia are very much popular in the region.

The stem and bark are the most commonly used plant parts for catching fish by tribal people of Nagaland [18]. The plant parts are pounded using a rock at the sides of the river and the crushed pieces are then sprayed into small pools where the water is stagnant. Sometimes leaves and fruits are cut open and kept submerged in water bodies with the help of stones. 'Fishing festival' is celebrated every year where local people gather together for catching fish using piscicidal plant. A number of plants significant for ethno-fisheries have been listed in KarbiAnglong district of Assam of which few are used as ethnotoxic. Fishers and villagers use Polygonum hydropiper, Albizzia odoratissima, Duranta plumier etc plants and their derivatives for catching fishes from natural waterbodies [52].

Among all the fishing methods practiced by the Nicobarese tribes, fish poisoning or stupefying by Barringtonia asiatica seeds locally called as Kinyav worth mentioning. Since the tree not only plays a vital role in harvesting of small to medium size fishes but also for various other purposes like healing diseases, making of canoe constructing of sitting stage, house, fire wood and handicrafts. Shompen tribes of Great Nicobar Island utilize the seed of for poisoning the fishes and trunk of the tree for making canoe $[68,69]$.

The plants used by the Santhal tribes of Purulia in West Bengal for capturing fishes are Casearia elliptica, Gardenia latifolia, Holarrhena pubescens, Madhuca indica, Plumbago zeylanica Polygonum barbatum, Schleichera oleosa, Strychnos nux-vomica etc, whose active components have been found in the root, seed, bark, stem, or leaves of the plants [42].

\section{Conclusion}

The use of plant derived fish poisons has been proved effective, economic and sustainable following their application over the years in variable geo-climatic situations targeting diversified fish species. As the society is becoming more concerned about the residual effects of chemical piscicides particularly in aquatic ecosystems, the plant based piscicides are becoming more pertinent towards a better management practice in pond based fish farming system anywhere in the globe with traditional to moderately intensive levels of operations. Besides acting as fish toxicants, all the herbal piscicides act as manure upon subsequent decomposition within the culture system which reduce the cost of manuring towards planktonic build up for the intended stock of fish seed. Therefore, plant derived piscicides were proved economical compared to the chemically processed piscicides. However, detailed inventory of the prospective plants having piscicidal properties from different parts of the globe is fragmentary and needs attention to be systematically evaluated and documented.

\section{References}

1. Pillay TVR, Kutty MN (2001) In: Aquaculture: Principles and Practices. pp: 253-257. 


\section{Journal of Ecology \& Natural Resources}

2. Hawkins CP (1984) Substrate associations and longitudinal distributions in species of Ephemerellidae (Ephemeroptera: Insecta) from western Oregon. Freshwater Invertebrate Bio 3(4): 181-188.

3. Shafi SM (2003) In: Applied Fishery Science. Atlantic Publishers and Distributors, New Delhi, India (2): 510.

4. Rath RK (1993) In: Fresh water Aquaculture. Scientific Publishers, Jodhpur, India, pp: 493.

5. Sarkhel C (2002) Comparative evaluation of some selected fish toxicants on certain environmental health parameters with special reference to nutrient cycling microbes. M. F. Sc. Thesis. West Bengal University of Animal and Fishery Sciences, Nadia, West Bengal, India.

6. Prevost G (1960) In: Use of fish toxicants in the Province of Quebec.

7. Hooper FF, Williams JE, Patriarche $\mathrm{MH}$, Kent $\mathrm{K}$, Schneider JC (1964) Status of lake and stream rehabilitation in the United States and Canada with recommendations for Michigan waters. Michigan Department of Conservation, Inst Fish Res Report pp: 56.

8. Klar GT, Schleen LP (2000) In: Standard operating procedures for application of lampricides in the Great Lakes Fishery Commission integrated management of sea lamprey (Petromyzon marinus) control program. U. S. Fish and Wildlife Service, Marquette Biological Station, Marquette, Michigan, Special Report 92001.3, pp: 912.

9. Fafioye 00, Adebisi AA, Fagade SO (2004) Toxicity of Parkia biglobosa and Raphia vinifera extracts on Clarias gariepinus juveniles. African J Biotech 3(11): 627-630.

10. Sirivam V, Babu MM, Immanuel G, Murugdass S, Citarasu T, Marian MP (2004) Growth and immune response of juvenile greasy grouper (Epinephelus tauvina) fed with herbal antibacterial active ingredient supplemented diets against Vibrio infections. Aquacul 237(1-4): 9-20.

11. Das SK, Sarkhel C, Mandal A, Dinda R (2017) Piscicides in Tropical Freshwater Aquaculture - An Overview India. J Anim Health 56(1): 11-30.
12. Wilhelm G (1974) The Mullein: Plant Piscicides of the Mountain Folk Culture. Geograph Rev 64(2): 235-252.

13. Kumar N (2009) Study on Suitable Piscicide for Sustainable Aquaculture Management. M. F. Sc. Thesis. West Bengal University of Animal and Fishery Sciences. Budherhat Road, Chakgaria, Kolkata, West Bengal, India.

14. Murthy EN, Pattanaik C, Reddy CS, Raju VS (2010) Piscicidal plants used by Gond tribe of Kawal wildlife sanctuary, Andhra Prades, India. Ind J Nat Prod Res 1(1): 97-101.

15. Tang YA (1961) The use of saponin to control predaceous fish in shrimp ponds. Prog Fish Cult 23: 43-45.

16. Westfall BA, Russell RL, Auyong TK (1961) Depressant agent from walnut hulls. Science 134(3490): 1617.

17. Chatterjee S, Ganguli S (1993) Effect of mahua oil cake on the blood of the fish Clarias batrachus. Environ Ecol 11(4): 888-891.

18. Dominic R, Ramanujam SN (2012) Traditional knowledge and ethnobotanical uses of piscicidal plants of Nagaland, North east India. India. J Nat Prod and Resources 3(4): 582-588.

19. Siememeon O, Ayoola MPK, Idowu AA, Adelekun AB (2011) Acute toxicity of Nile tilapia juveniles exposed to aqueous and ethanolic extracts of Ipomea aquatic leaf. J Nat Sci 9(3).

20. Istvan U (2000) Semi-natural products and related substances as alleged botanical pesticides. Pest Manage Sci 56(8): 703-705.

21. Botha CJ, Penrith ML (2008) Poisonous plants of veterinary and human importance in southern Africa. J Eth pharmacol 119(3): 549-558.

22. Tiwari S, Singh A (2003) Control of common freshwater predatory fish, Channa punctatus, through Nerium indicum leaf extracts. Chemosphere 53(8): 865-875.

23. Katewa SS, Jain A, Chaudhary BL, Galav PK (2006) Some unreported medicinal uses of plants from the tribal area of southern Rajasthan. Bull Bot Surv India 47(1-4): 121-130. 
24. Olufayo MO (2009) Haematological characteristics of Clarias gariepinus (Burchell 1822) juveniles exposed to Derris elliptica root powder. Africa J Food Agri Nutri Dev 9(3): 921-933.

25. Chakroff M (1976) In: Fresh water fish pond culture and management. Volunteers in Technial Assistance, Vita Publications, USA.

26. Mahapatra BC, Thosar VR (1999) In: Toxicity of plants and their derivatives on fishes. pp: 360- 371.

27. Kamalkishor HN, Kulkarni KM (2009) Fish stupefying plants used by the Gond tribal of Mendha village of Central India. Ind J Trad Knowl 8(4): 531-534.

28. Clearwater S, Hickey CW, Martin ML (2008) In: Overview of potential piscicides and molluscicides for controlling aquatic pest species in New Zealand. Science and Technical Publishing, Wellington, New Zealand, pp: 22-27.

29. Kanaujia DR, Jena S, Mohanty AN (1981) Note on the effect of mahua oil cake on zooplankton. Ind J Anim Sci 51(2): 257-260.

30. Willis K, Ling K (2000) Sensitivities of mosquito fish and black mudfish to a piscicide: could rotenone be used to control mosquito fish in New Zealand wetlands?. New Zeal J Zool 27(2): 85-91.

31. Rowe D (2003) Rotenone-based approaches to pest fish control in New Zealand. In: Managing invasive freshwater fish in New Zealand. Proceedings of a workshop hosted by the Department of Conservation, 10-12 May 2001, Hamilton. Department of Conservation, Wellington pp: 131-142.

32. Solman VEF (1950) History and use of fish poisons in the United States. Canadian Fish Cult 8: 3-16.

33. Yadav RP, Singh A (2001) Environmentally safe molluscicide from two common euphorbiales. Iberus 19: 65-73.

34. Hassal KA (1982) In: The Chemistry of Pesticides. Macmillan press, London, pp: 372.

35. Bardach IE (1968) Fish Culture, Part III. In: The status and potential of aquaculture, particularly fish culture, Springfield 2: 1-225.

36. Konar SK (1970) Nicotine as a fish poison. Prog Fish Cult 32(2): 103-104.
37. Minsalan CO, Chiu YN (1986) Effects of tea seed cake on selective elimination of finfish in shrimp ponds. In: The First Asian Fisheries Forum. Asian Fisheries Society, Manila, Philippines, pp: 79-82.

38. Vanichkul K, Hamthanon V, Siripong T (2014) Acute Toxicity of Tea Seed Cake on Climbing perch (Anabas testudineus (Bloch)). Int J Env Rur Dev 5(2): 126.

39. Jhingran VG, Pullin RSV (1985) A hatchery manual for the common, Chinese, and Indian major carps (No. 252). World Fish pp: 63.

40. Krishan R (2016) Plant Used as Toxin for Collection of Fishes. Int J Adv Res Sci Eng 5(11): 124-136.

41. Nasiruddin M, Rahman M, Akhter R (2009) Toxic response of Heteropneustes fossilis (Bloch) to some indigenous plant seed extracts. Chittagong Univ J Bio Sci 4(1\&2): 1- 12.

42. Raha S, Mallick H (2016) Piscicidal and Fish Stupefying Plants used by Tribal people living around Panchakot hills, Purulia, West Bengal, India. Int J Life Sci 5(1): 27-30.

43. Negi KS, Kanwal KS (2009) Plants used as fish toxins in Garhwal region of Uttarakhand Himalaya. Ind J Trad Knowl 8(4): 535-538.

44. Rajput V, Gaur R (2015) Toxicological study on Clarias batrachus caused by Croton and Mahua extract. J Pharmacog Phytochem 3(6).

45. Kerezsy A (2009) In: Gambusia control in spring wetlands. South Australian Arid Lands Natural Resources Management Board, final report, Govt. of South Australia.

46. Zhao BL, Fang L, Zhang JE, An M, Wang RL, et al. (2015) Effects of five exotic invasive plants extracts on the survival of the invasive snail Pomacea canaliculata (Lamarck). Allelopathy J 36(1): 1231321.

47. Dimri M (2008) In: Chemical analysis of some plants of Garhwal Himalaya as Biopesticideis. India.

48. Sinha MK, Munshi JD (2010) In: Eco-toxicology of biocidal plants. Mittal Publications, New Delhi, India, pp: 91.

49. Dixit U (2011) Traditional knowledge from and for elderly India. J Trad Knowl 10(3): 429-438. 
50. Alagesaboopathi C (2012) Poisonous Plants of the Salem District of Tamilnadu, Southern India. J Phar Res 5(10): 5039-5042.

51. Banouzi JT, Prost A, Rajemiarimiraho M, Ongoka P (2008) Traditional uses of the African Millettia species (Fabaceae). Int J Botany 4(4): 406-420.

52. Kalita B, Dutta A, Choudhury M (2007) Herbal fish toxicant used by fishers of Karbi-Anglong district, Assam. Ind J Trad Knowl 6(2): 334-336.

53. Oti EE, Ukpabi UH (2005) Acute toxicity of water extracts of barks of yellow oleander, Thevetia peruviana (Persoon), and neem plant, Azadirachta indica (Lodd) to Mormyrids, Hyperopisus bebe occidentalis (Gunther). J appl Aquacul 16(3-4): 183190.

54. Singh SK, Yadav RP, Singh A (2010) Piscicidal activity of leaf and bark extract of Thevetia peruviana plant and their biochemical stress response on fish metabolism. Eur Rev Med Pharm Sci 14(11): 915-923.

55. Jeremy SO (2002) Fish poison use in Americas.

56. Lin KW (2005) Ethnobotanical studies of medicinal plants used by Jah Hut peoples in Malaysia. Ind J Med Sci 59(4): 156-161.

57. Tag H, Das AK, Kalita P (2005) Plants used by the Hill Miri tribe of Arunachal Pradesh in ethnofisheries. Ind J Trad Knowl 04(1): 57-64.

58. Neuwinger HD (2004) Plants used for poison fishing in tropical Africa. Toxicon 44(4): 417-430.

59. Chopra RN, Chopra IC, Handa KL, Kapur LD (1958) Chopra's Indigenous Drugs of India. 2nd (edn.), U. N. Dhur and Sons, Calcutta, pp: 395.
60. Rammanujam SN, Ratha BK (1980) Studies on piscicidal plant of North-eastern India: Hope for an indigenous plant poison for the fish nursery management. Curr Sci 49: 251-252.

61. Dinesh J (2010) Piscicidal plants used by Bhil tribe of Ratlam district (M. P.), India. J Econ Taxon Bot 34: 757-759.

62. Prasad KS, Raveendran K (2011) Plants used as fish poison in Kasargod district, Kerala. J Ecobiol 28(2): 101-105.

63. Rao RM (1914) In: Flowering Plants of Travancore. The Government Press, Trevancore, India.

64. Prasad KS, Raveendran K (2011) Plants used as fish poison in Kasargod district, Kerala. J Ecobiol 28(2): 101-105.

65. Sasi SA, Mohan M (2018) Piscicidal plants used by Malai Pandaram tribes in Achankovil river basin, Kerala: an ethnobiological approach. Int J Adv Res 6(1): 726-730.

66. Bourdillon TF (1892) Report on the Forests of Travancore. (Government Press, Trivandrum), pp: 59.

67. Heda NK, Kulkarni KM (2009) Fish stupefying plants used by the Gond tribal of Mendha village of Central India. Ind J Trad Knowl 8(4): 531-534.

68. Elanchezhian RS, Senthil KR, Beena SJ, Suryanarayana MA (2007) Ethnobotany of Shompens- a primitive tribe of great Nicobar Island India. J Trad Knowl 6(2): 342-345.

69. Ravikumar T, Dam-Roy S, Krishnan P, Sankaran M, Sachithanandam V (2015) Traditional usages of ichthyotoxic plant Barringtonia asiatica (L.) Kurz. By the Nicobari tribes. J Marine Island Cult 4(2): 76-80.

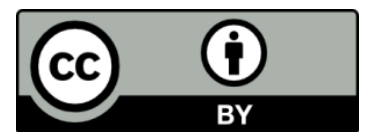

